\title{
Cornography: Selling Women's Professional Basket- ball in a Girls' Basketball State
}

\author{
SHELLEY LUCAS
}

ON MARCH 21, 1978, the newly formed Women's Professional Basketball League (WBL) awarded its first team franchise to Iowa. One of several short-lived professional women's leagues in the 1970s and 1980s, the WBL launched its inaugural season in December 1978 with a roster of eight teams. ${ }^{1}$ George Nissen, the Cedar Rapids native known for making the trampoline a household word and a longtime benefactor of amateur American gymnasts through his company, Nissen Equipment, bought the Iowa franchise and named the team the Iowa Cornets. Nissen chose the name to suggest that the team belonged to the whole state rather than to a particular city and to recognize Iowa's reputation as the "corn" state. The team not only took the state's name but also initially played its home games in eight different cities in an effort to gain statewide support. ${ }^{2}$ Nissen compared

1. Besides the Iowa Cornets, the league included the Chicago Hustle, Dayton (Ohio) Rockettes, Houston Angels, Milwaukee Does, New Jersey Gems, and New York Stars. For a detailed description of the WBL and stories documenting the firsthand experiences of those involved with the league, see Karra Porter, Mad Seasons: The Story of the First Women's Professional Basketball League, 19781981 (Lincoln, NE, 2006). Porter interviewed more than 100 players, coaches, and administrators, including the league's founder, Bill Byrnes. For a more analytical approach to the WBL's short history, see Mary Jo Festle, Playing Nice: Politics and Apologies in Women's Sports (New York, 1996), 248-64.

2. The first season, the Iowa Cornets played its 17 home games in auditoriums and high schools located across the state: in Bettendorf, Cedar Falls, Cedar THE ANNALS OF IOWA 64 (Fall 2005). (C) The State Historical Society of Iowa, 2005. 
his financial venture to growing corn: "The word corn is in there and if you put enough fertilizer on corn it will grow." 3 The team colors (green and gold), a similarly painted team bus called the "Corn Dog," and a short-lived mascot (an ear of corn) named Shucks were all part of "cornography" - Nissen's term for the excitement generated by the team. ${ }^{4}$

Iowa was known nationally not only for corn but also for its support of high school girls' basketball, a phenomenon that Nissen and the Cornets hoped would carry over to women's professional basketball. In an era when girls and women had historically received minimal resources, encouragement, opportunities, or recognition for participating in competitive sports, Iowans wholeheartedly embraced high school girls' basketball - but only the version played in their state. ${ }^{5}$

Rapids, Council Bluffs, Des Moines, Ottumwa, Sioux City, and Spencer. Minnesota Fillies' General Manager Gordon Nevers expressed concern about the image created by the Cornets' marketing strategy, particularly its home game setup. He suggested that the Cornets were detracting from the impression of "big-time basketball" through the "barnstorming image" created by the plan to play home games in different towns. Gordon Nevers quoted in Bob Dyer, "Should Cornets Stop 'Barnstorming'?" Des Moines Register, 1/16/1979, in Newspaper clippings, 1978-1980, box 1, Iowa Cornets Records (hereafter cited as ICR), Iowa Women's Archives (IWA), University of Iowa Libraries, Iowa City. Although the Cornets were the only team to play its home games at several sites during the first season (the team played only in Cedar Rapids and Des Moines during the second season), it was not the only team to play in small venues. Renting small gymnasiums, including high school facilities, was part of the WBL's plan to keep costs down. According to Festle, Playing Nice, 250,260 , one observer commented that the facilities reminded him of a church league.

3. Ron Maly, "Nissen Gambling on Women Cagers," Des Moines Register, undated, Newspaper clippings, 1978-1980, box 1, ICR.

4. George Nissen referred to Iowa's reputation as a corn state in a number of media sources, including newspapers and publicity materials. See ICR, particularly the newspaper clippings and publicity folders; see also "King of Cornography," Scrapbook, 1978-1979, box 2, IWA.

5. An increasing array of scholarship is available concerning women's sport history, including sport-specific publications, those that cover women's sport and physical activity more generally, and the inclusion of women and gender as areas of inquiry within historical examinations that had previously excluded them. Key texts that I draw on for this work include Susan K. Cahn, Coming on Strong: Gender and Sexuality in Twentieth-Century Women's Sport (New York, 1994); Festle, Playing Nice; and Joan S. Hult and Marianna Trekell, eds., A Century of Women's Basketball: From Frailty to Final Four (Reston, VA, 1991). 


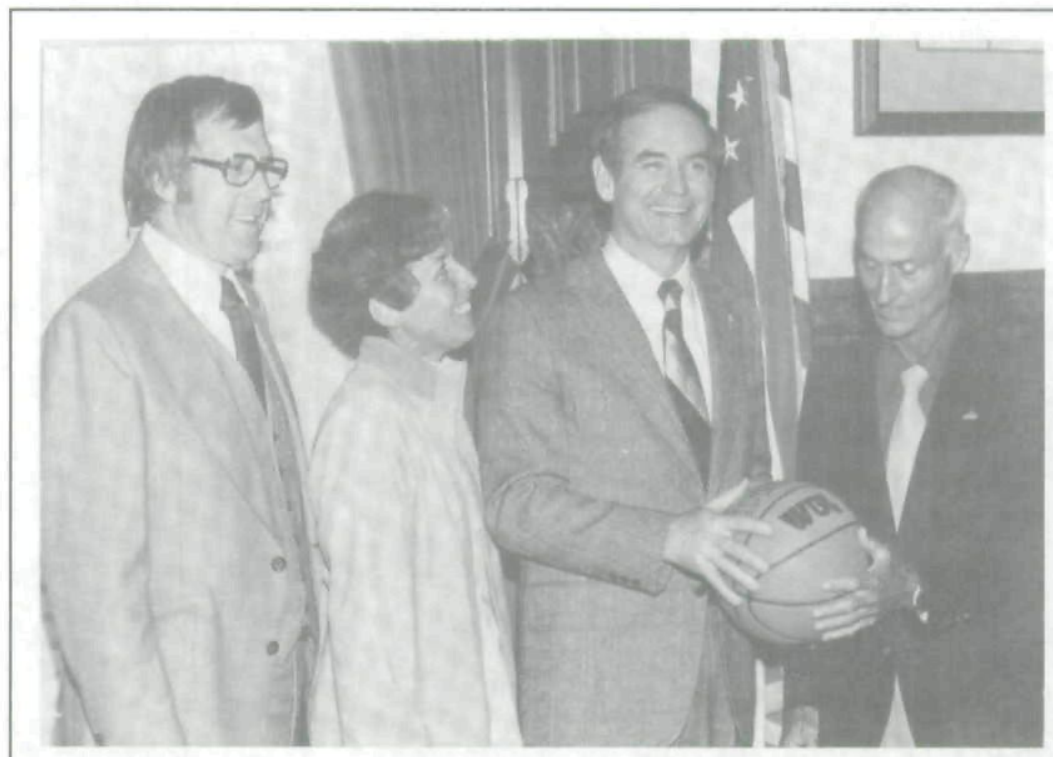

Cornets owner George Nissen (far right), his wife, and Cornets General Manager Rod Lein (left), pose with Governor Ray before the team's first season. All photos in this article courtesy of Iowa Women's Archives.

In the late 1970s Iowa still played the 6-player, half-court game, known as 6-on-6, while in all but a few states, the 5player, full-court game (5-on-5) had become the norm. Despite the change in national women's basketball rules from the 6player to the 5-player game in 1971, Iowa continued to play by the old rules, and would continue to do so (in many parts of the state) until 1993.6

The basic differences between the two games were striking: the 6-on-6 game featured teams of six players, three defensive

6. In 1969 the National Women's Basketball Committee (of the Division for Girls and Women in Sports) decided to test the full-court, 5-player game as experimental rules. After only one year of a planned two-year trial, the committee made the new rules official in 1971. Only Iowa and a few other states did not adopt these rules. Joanna Davenport, "The Tides of Change in Women's Basketball Rules," in Hult and Trekell, eds., A Century of Women's Basketball, 92. Beginning with the 1984-85 season, the Iowa Girls' High School Athletic Union sponsored both the 5-player and 6-player rules and would continue to do so until announcing in 1993 that the 6-player rules would be retired. For an extended discussion of the rules controversy, see Shelley Lucas, "Courting Controversy: Gender and Power in Iowa Girls' Basketball" (Ph.D. diss., University of Iowa, 2001). 
(guards) and three offensive (forwards), separated by the halfcourt line. Only forwards could shoot and score. All players were limited to two dribbles and confined to their half of the court. Essentially, 6-on-6 resembled two games of 3-on-3, but with only one game (and half of the players) in action at any given time. The 5-player game, in contrast, featured teams of five players who could freely travel continuously up and down the full court with unlimited dribbles, and all players were eligible to score points.

In the midst of preparations for the Cornets' inaugural season, Iowa's 6-on-6 game faced legal challenges stemming from Title IX-the landmark federal legislation that outlawed sex discrimination in federally funded educational programs, including sports - that were based on the argument that the 6player game discriminated against girls. The dispute over the Iowa high school girls' basketball rules took place alongside and within social and political conflicts related to national and local debates surrounding Title IX, Equal Rights Amendment initiatives, and, more generally, the women's liberation movement. Iowans watched the legal battles developing over their high school girls' basketball rules closely-some in anticipation, many with trepidation. The ensuing debate over the rules captured the attention of not only the state and its leaders, but the Iowa Cornets organization as well. In the midst of all this controversy, the organization was attempting to sell the 5-player brand of basketball to a fan base reportedly largely resistant to it.

Meanwhile, the newly formed WBL also sought ways to sell women's professional basketball to a national audience that was not accustomed to watching or supporting women's team sports. According to historian Mary Jo Festle, the national debates concerning women's professional basketball were not so much over whether females could play "real" basketball (5-on-5), but over whether those who excelled were "real" females.7 Until 1971, the 5-player, full-court rules had been played predominantly by males, while females participated in modified versions of basketball (such as 3-court, 2-court, and rover) designed both to limit exertion and physical contact and to accommodate prevailing

7. Festle, Playing Nice, 248-64. 
social, cultural, and medical beliefs about females' ability to play sports. ${ }^{8}$ Because male-defined sport equated athleticism with masculinity, women who participated in sport disrupted this equation and often had their sexuality and gender called into question-even more so if they excelled. Festle and others have argued that the WBL attempted to dispel this age-old association of female athleticism with masculinity by resorting to feminine apologetic behavior, primarily by emphasizing and highlighting the femininity and assumed heterosexuality of the players.

In this article, I focus primarily on the Iowa Cornets' locally specific and uniquely Iowan marketing plan to promote its team. The most aggressive marketing and media coverage occurred in anticipation of and during the first season, 1978-79, beginning with the first reports that Nissen had been contacted about the possibility of buying a franchise in the WBL, with a somewhat smaller production the following season, 1979-80. After two successful seasons (twice placing second in the league), the team folded; the WBL would follow suit the next year. My purpose is not to provide a history of the Cornets (or the WBL) or the reasons for its failure-both Karra Porter and Mary Jo Festle, among others, have discussed these topics - but rather to situate this Iowa venture within a national context and explore how the marketing strategies targeted Iowans and were mediated within local and national discourses.

Although the Cornets' marketing strategies did reflect both local and national debates concerning women's basketball, during the Cornets' first season in particular, its strategies differed from the WBL management's adoption of feminine apologetic behavior to sell the league. After briefly discussing the apologetic, as a concept and a behavior, used by sport studies scholars and in conjunction with the WBL, I focus specifically on the Iowa Cornets' locally distinct marketing strategies. The Cornets went against the grain of the WBL's national media and marketing strategies by not relying on apologetic strategies to fill the stands, at least not initially, and not to the extent of the rest of

8. For an excellent overview of women's basketball history, including rule changes and the social, cultural, and medical factors underlying the sport's history, see Hult and Trekell, eds., A Century of Women's Basketball. 
the league. Iowans had long accepted and applauded girls' participation in competitive athletics (at least in small towns and rural areas), starting with and starring girls' basketball, but including a wide range of other sports by this time, despite a longstanding philosophical opposition to competitive sports by national leaders in physical education for girls and women that had only begun to significantly shift in the previous ten to fifteen years. ${ }^{9}$ Thus Iowa offered an environment in which apologetic strategies adopted by the WBL seemed unnecessary.

I argue that the Cornets' story interrupts the national narrative. Instead, the Cornets drew on local history and culture and, more specifically, the local pride and national attention associated with the agricultural boon of corn production and the long-standing tradition of girls' basketball - two of Iowa's bestknown legacies. In other words, the Iowa Cornets' initial marketing strategy was to closely associate itself with the state of Iowa. Nissen's colorful term cornography is especially suited to describe this marketing strategy. The team name, green and gold uniforms, mascot, schedule, and team bus communicated the homegrown association with corn (despite some Iowans' embarrassment). ${ }^{10}$ Iowa girls' basketball-long recognized as a unique part of Iowa's history, culture, and identity - also be-

9. The University of Iowa's Department of Physical Education for Women housed some of these national leaders. Along with other faculty members at Iowa's colleges and universities, department chairpersons Elizabeth Halsey (1924-1955), M. Gladys Scott (1955-1974), and N. Peggy Burke (1978-1987) each sought to modify the Iowa girls' basketball program with the goal of providing sport experiences for girls in line with their philosophies of education and sport-and these philosophies shifted over time. See Lucas, "Courting Controversy."

10. In the Des Moines Register's pre-game coverage of the Cornets' home opener, business writer Dan Piller described "local embarrassment about Iowa's corny heritage" and stated that many Iowans "blanched" when learning of Nissen's decision to name the team the Cornets, and even more so when he "made sure everyone got the point by choosing corn's primary colors for the team." Nissen himself noted that the Iowa Development Commission staff was upset with him because they were trying to establish an industrial image for Iowa, to which he is quoted as replying, "But can't we be secure enough about our heritage to advertise it now rather than ashamedly hiding it?" Dan Piller, "These Cornets Play a Bouncy Tune," Des Moines Register, 12/17/1978, Scrapbook, 1978-1979, box 2, Bolin Papers. In response to the unveiling of the team mascot, "Shucks," Iowa journalist Gene Raffensberger wrote, "Most Iowans groan at being depicted as corny." Unidentified clipping, 12/24/1978, ibid. 
came an integral part of cornography in a variety of ways. I explore how the Cornets negotiated the tension originating in a need to promote the 5-player game to fans of 6-on-6, especially when many Iowans were concerned that girls could not effectively play full-court basketball-or should not. An awareness of the popularity and tradition of 6 -on- 6 , the signing and promotion of Iowa players, and an acknowledgment of the anxieties concerning ongoing legal and cultural threats to this style of play were important parts of the Cornets' strategy.

"THE APOLOGETIC," or apologetic behavior, a concept defined by Jan Felshin in 1974 within the framework of role conflict theory, originated as an individual response to an assumed incompatibility between womanhood and athleticism. Susan Cahn refers to this incompatibility as the central, underlying tension in American women's sports history throughout the twentieth century. She provides countless examples, ranging from the dress and behavior codes applied to athletes in sports such as baseball (All-American Girls Baseball League) and track and field (Tennessee State University), to the genetic testing (sex testing) previously mandated for female athletes by the International Olympic Committee. ${ }^{11}$ The apologetic refers to behaviors or responses developed by some women "to account for their sport involvement in the face of its social unacceptability." 12

As women's participation in sport has generally grown more acceptable, scholars suggest that the apologetic has increasingly come to be used to deflect questions about an ath-

11. Cahn, Coming on Strong, 4. The IOC discontinued mandatory genetic testing of female athletes in 1999 after more than 30 years of the practice.

12. Jan Felshin, "The Triple Option for Women in Sport," Quest, January 1974, 36. Felshin (36-40) identifies several variations or forms that the apologetic may take, including presenting an excessively "feminine" appearance (through makeup, jewelry, clothing), denying the importance of sport in one's life, selecting feminine-appropriate sports, citing the attainment of feminine values, such as beauty, grace, and a toned physique as justification for playing, and supporting a traditional and conservative view of women's place in society. Each of these apologetics helps to demonstrate that the athlete is, indeed, a real woman - unchanged by her involvement in sport. See also Mary A. Boutilier and Lucinda SanGiovanni, The Sporting Woman (Champaign, IL, 1983), 33-36, 109-10, 115-16. 
lete's sexuality. Use of the term apologetic has expanded correspondingly beyond its origins in role conflict theory and individual behavior and is now commonly used by historians and sport studies scholars to implicate the media and sport organizations. Such groups, for example, "apologize" for female athletes by overemphasizing their femininity and heterosexuality. Scholars rely on this broader adoption of the concept when they describe how the WBL dealt with its "image problem" and fears about femininity and sexuality. ${ }^{13}$

The WBL used publicity and promotional gimmicks to highlight the femininity and assumed heterosexuality of the players. For example, one team was sent to a five-week modeling course under threat of a fine, and exhibition games were scheduled against Playboy Bunnies. Information about players' grooming habits, hair, and dress appeared in reports about the league. Arguing that sometimes the league "sold sex as much as the athletes' abilities," Festle offers examples of WBL management admitting that players who projected the "right" feminine image helped with promotions and crowd appeal. By catering to the sexist attitudes of the audience instead of promoting the athletes' abilities, the tactic delayed real acceptance of women as serious, professional athletes. ${ }^{14}$ Many players lamented having to put up with the "beauty ideals of the owners and some of the fans instead of their own sporting ideals." 15 One former player even suggested that one of the reasons the league failed was because the press was more interested "in pin-ups than lay-

13. For discussions and examples of the development and practice of apologetic behavior from throughout the twentieth century, see Cahn, Coming on Strong; Festle, Playing Nice; Rita Liberti, “'We Were Ladies, We Just Played Basketball Like Boys': African American Womanhood and Competitive Basketball at Bennett College, 1928-1942," Journal of Sport History 26 (1999), 567-84; Pat Griffin, Strong Women, Deep Closets: Lesbians and Homophobia in Sport (Champaign, IL, 1998); and Nancy Theberge and Susan Birrell, "The Sociological Study of Women and Sport," and "Structural Constraints Facing Women in Sport" in D. Margaret Costa and Sharon R. Guthrie, eds., Women and Sport: Interdisciplinary Perspectives (Champaign, IL, 1994), 323-40.

14. Festle, Playing Nice, 253-57, 164-65; Susan Stilton, "How to Be Charming While Dribbling," Ms., October 1980, 25.

15. Marianna Trekell and Rosalie M. Gershon, "Title IX, AIAW, and Beyond: A Time for Celebration," in Hult and Trekell, eds., A Century of Women's Basketball, 413 . 


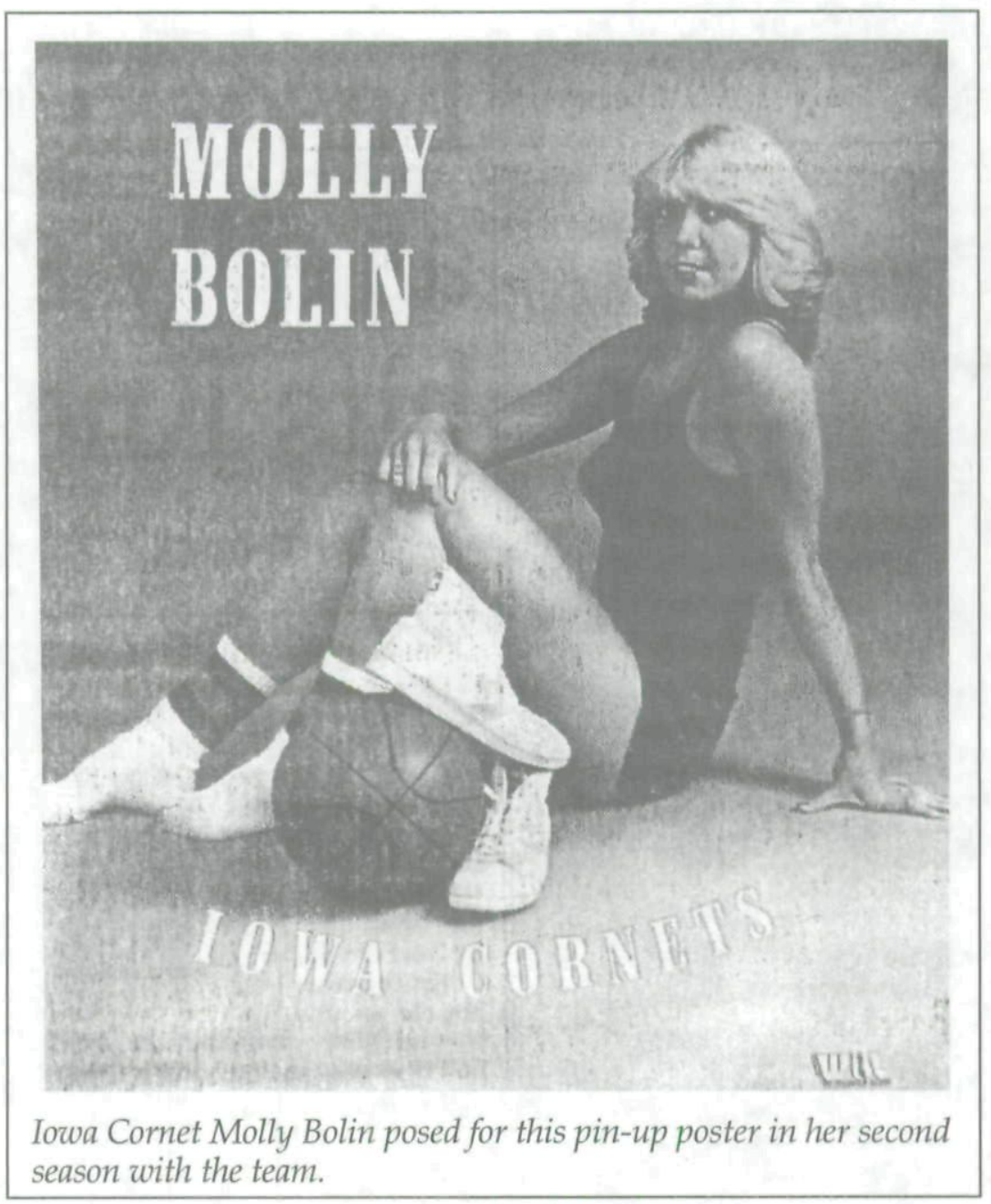

ups."16 But Anne Meyers, a New Jersey Gems player, responded, "In order for people to accept the WBL, they want to know that we are women. It's not fair, but it's a fact of life." 17

16. The former player is Donna Geils, who published a story about the WBL in the New York Times, 11/15/1981, cited in Donald F. Staffo, "The History of Women's Professional Basketball in the United States with an Emphasis on the Old WBL and the New ABL and WNBA," Physical Educator 55 (1998), 187-98; see also Festle, Playing Nice, 254.

17. Stilton, "How to Be Charming While Dribbling," 25. 
One of the players who became known for her pin-ups was Iowa Cornet Molly Bolin, a former Moravia, Iowa, high school standout, married and with one child, who admittedly took it upon herself in the second season to fill the stands by posing for and selling pin-up posters. The posters featured Bolin, described by Des Moines Register columnist Chuck Offenburger as "sexy, though wholly decent," posing in her uniform for one poster and in a tank top and shorts for another. Explaining that "you don't have to throw your femininity away to be a top competitor," Bolin continued to appear in publicity that highlighted her femininity and sexuality as she made her way through several professional women's basketball leagues. As the clothing in her publicity shots evolved from a uniform to a swimsuit to a mink coat and high heels (and presumably nothing else), her image moved further away from the "wholly decent" description associated with her first foray into professional basketball promotion. ${ }^{18}$ Bolin's apologetic behavior, however, is an exception in the generally uniquely Iowa approach the Iowa Cornets took to marketing during the team's first season.

IOWA'S LONG-STANDING SUPPORT for girls' high school basketball would seem to preclude a need for apologetic strategies from the Cornets. That is not to say that the Iowa girls' basketball program did not include apologetic behavior-it did. The Iowa Girls' High School Athletic Union (IGHSAU) had a history of promoting the femininity of basketball players, par-

18. Chuck Offenburger, "Our Molly Now a Mink," Des Moines Register, 11/11/ 1984, Columbus Minks folder, box 1, 1984, Bolin Papers; unidentified newspaper clipping, Newspaper clippings and interviews, 1981-1997, box 1, Bolin Papers. According to media reports, the Cornets advanced the funds for 1,000 posters at Bolin's request. The posters sold out and Bolin kept the profits. She also appeared on the second season's schedule posters and "let the Cornets warm you up this winter" television commercials. Carrie Muskat, "Machine Gun Molly Just Doing Her Thing," Cedar Rapids Gazette, 1/23/1980, Newspaper clippings, 1978-1980, box 1, ICR. After the Iowa Cornets folded, Bolin played for the San Francisco Breeze (Ladies Professional Basketball Association, 1980), San Francisco Pioneers (WBL, 1981), and Columbus Minks (Women's American Basketball Association, 1984). Bolin's comments about her posters and other promotional activities are featured in a number of newspaper clippings about the WBL and other subsequent professional women's basketball leagues. See Bolin Papers. 
ticularly through the Iowa Girls' Basketball Yearbook and state tournament rituals. The Yearbook included articles emphasizing personal appearance, marriage prospects of players, and girls' proclivity to emotional expression-a distinctly female expression (such as crying over wins and losses), among many other topics. ${ }^{19}$ The rituals and practices associated with the Iowa girls' state tournament, including the queen contest, the half-time dance routines, and the wearing of corsages during pre-game warm-ups, helped the IGHSAU (and perhaps even the players themselves - although the tournament has been a tightly orchestrated event run by the IGHSAU) to highlight and also construct femininity. The emphasis on femininity in these IGHSAU practices served as a way to justify its basketball program during the middle decades of the twentieth century when national leaders in women's physical education and sport opposed such highly competitive sport programs. The attention to femininity did not come at the expense of highlighting the girls' athleticism and competitive drive; rather, the IGHSAU constructed a femininity specific to Iowa, taking into account Iowa's agricultural and cultural specificities and histories. This version of femininity - what I call "farm-girl femininity" - incorporated physicality and a rural Iowa heritage. ${ }^{20}$

19. The IGHSAU is the administrative body that governs high school sports for girls in Iowa. It was then, and is now, the only separate high school athletic association for girls in the country. The IGHSAU formed in 1925 after the Iowa High School Athletic Association (the current association for boys' athletics) voted to drop sponsorship of the girls' basketball tournament. For additional information about the IGHSAU, see Janice A. Beran, From Six-on-Six to Full Court Press: A Century of Iowa Girls' Basketball (Ames, 1994). Iowa Girls' Basketball Yearbooks were published from 1944 to 1964 . The yearbooks included everything from in-depth coverage of competitions, grooming tips, gossip columns, and weight training plans to professional research articles that were presented as justification for the game in response to the women physical educators' campaign against the evils of competitive basketball. See Lucas, "Courting Controversy," 57-58.

20. For detailed information about the early years of Iowa high school girls' basketball and the factors associated with Iowa's rural heritage, educational philosophy, identity, and values that helped to shape and support the sport up to the final shift away from the 6-player rules, see Janice A. Beran, "Playing to the Right Drummer: Girls' Basketball in Iowa, 1893-1927," Research Quarterly for Exercise and Sport (Centennial issue, 1985), 78-85, and idem, From Six-on-Six to Full Court Press. 
The national media picked up on this femininity and highlighted what they constructed as a unique confluence of rural Iowa, 6-on- 6 rules, and homecoming queen star players as a way to explain this strange phenomenon of sell-out crowds for a girls' sport in a national culture that recognized sport as a masculine domain. For example, a 1940 Life magazine photo essay titled "Pretty Virginia Harris Leads Hansell to Iowa Basketball Championship" featured Harris in Des Moines doing activities "every country girl visiting the big city dreams about." 21 An illustration of farm-girl femininity appeared in the Boston Globe in 1962 in a story unrelated to basketball, but it presented a similar, and apparently widely shared, picture of Iowa girls' physicality: "The Bostonian's mental picture of an Iowa coed shows a girl, blonde and blue-eyed, buxom and strong enough to throw a heifer from the pasture into the bin of surplus oats." 22 A number of press accounts rooted the success of Iowa girls' basketball firmly in agriculture. Sports Illustrated seemed to be especially captivated with the rural element of the Iowa girls' basketball story. In 1969 the magazine explained to readers that many girls learn and develop the physical skills required for farm work and basketball "as soon as they can tie their sneakers." Twenty years later (and after the demise of the WBL), two teammates were described as "a duo designed for six-on-six hoops the way a combine fits a cornrow." 23

Iowans who played for the Cornets were similarly characterized. Sports Illustrated labeled Bolin as "the girl from the cornfields" and explained that she "took up basketball at the age of 12 because it was what every good little Iowa girl did." 24 A Cornets season program identified Nancy Wellen as having grown up on a farm, and noted that Connie Kunzmann baled

\section{Life, 4/8/1940, 41.}

22. "Relaxing in Iowa," Boston Globe, 9/26/1962, reprinted in Ames Daily Tribune, 10/2/1962, Relaxation folder, box 20, University of Iowa Department of Physical Education for Women Records, IWA. The editorial pertained to a relaxation course offered by the University of Iowa's Department of Physical Education for Women.

23. Rose Mary Mechem, "Les Girls in Des Moines," Sports Illustrated, 2/17/1969,

39; Kevin Cook, "The Iowa Girl Stands Tall," Sports Illustrated, 2/13/1989, 81.

24. Roy S. Johnson, "The Lady is a Hot Shot," Sports Illustrated, 4/6/1981, 32. 


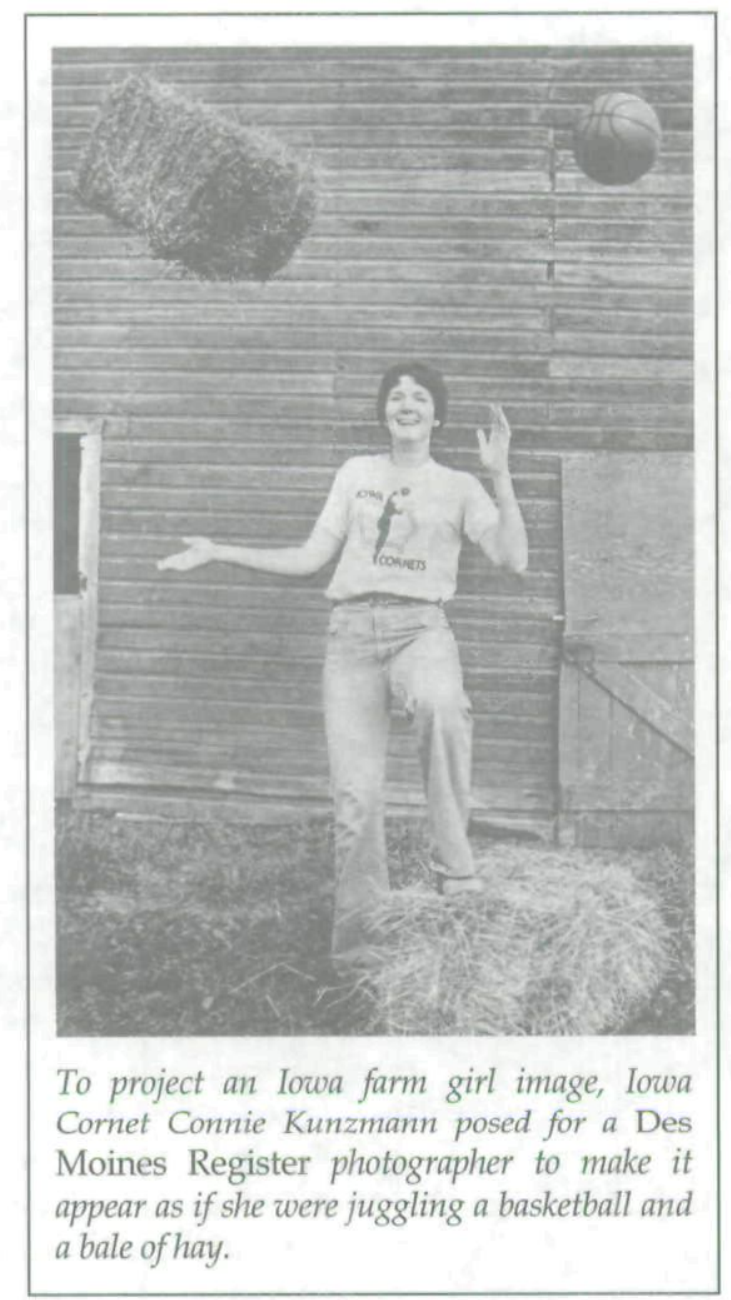

hay in the summer to stay in shape for basketball. The Des Moines Register published a piece on Kunzmann's farm background that featured a photograph of her apparently juggling a hay bale and a basketball. The column described her off-season training regimen as baling hay and walking beans, explaining that "the strength she developed doing farm chores as a girl helped make her a star player on the Everly Cattlefeeder teams that for several years dominated girls' basketball in Iowa." Kunzmann concluded that "you can't help but build strength" 
stacking hay bales weighing 25 to 50 pounds. ${ }^{25}$ Such excerpts not only show an almost relentless effort to connect Iowa to its farm heritage, but they also serve to construct Iowa's basketball heritage, which was-as documented in Iowa history scholarship-largely located in small schools and rural areas. ${ }^{26}$ The Cornets management hoped that what worked for Iowa girls' basketball would work for the Cornets, too. Thus the Cornets sought to tap into the success of the Iowa high school program.

\section{BECAUSE THE CORNETS were based in a state that pas-} sionately supported a highly competitive girls' basketball program, by all public appearances the Cornets did not expect there to be an "image problem" with its players. Instead, the team's management concerned itself with promoting state pride in an effort to sell spectators on the new game in town. The Cornets marketed "Iowa pride" in its efforts to garner a level of spectator support similar to what the girls' high school basketball program enjoyed. ${ }^{27}$ Through recruiting, marketing, press

25. "On the Cornets," Season Program, 1979-1980, box 1, ICR; Chuck Offenburger, "She Tosses Bales and Basketballs," Des Moines Register, 1979, Newspaper clippings, 1978-1980, box 1, ICR.

26. The pool of Iowa players that the Iowa Cornets could draw from in the late 1970 s would have been primarily composed of players from small towns and small schools who had further developed their talent at the college level. The growth in the number of players based in urban areas would have been under way as the Cornets team formed. That growth can be attributed to a variety of factors, including population shifts in Iowa and the passage of Title IX in 1972, which contributed to the increased number of larger (primarily urban) high schools that offered competitive girls' basketball programs. The number of schools offering girls' basketball grew from 332 in 1971 to 493 in 1980 and 581 by 1990. Beran, From Six-on-Six to Full Court Press, 100. Sportswriter Jim Enright, Only in Iowa: Where the High School Girl Athlete Is Queen (Des Moines, 1976), voiced concerns over the competitive impact of larger schools on the traditionally dominant smaller schools, which, at the time of publication, was a more pressing threat to the small-school-oriented 6-on-6 than a legally mandated rules change. See also Dorothy Schwieder, Iowa: The Middle Land (Ames, 1996), 169 , who includes Iowa girls' basketball in her history of Iowa as an illustration of town life and community in the first decades of the twentieth century.

27. Another short-lived women's professional basketball league took up this strategy with a more straightforward approach. Molly Bolin, in her capacity as the assistant commissioner of the newly formed National Women's Basketball Association (NWBA), announced that Iowa would be the home of "The Pride of Iowa," one of eight teams in the league. Unfortunately, The Pride of Iowa 
releases and media coverage, the team was careful not to offend the basketball aficionados it hoped to attract. Management offered support for the 6-player game while simultaneously promoting the 5-player women's professional game-the very game many Iowans were loath to see their high school girls play. For the Cornets, this pride rested on two key areas of recognition: girls' basketball and Iowa's reputation as an idyllic heartland and breadbasket for the country.

The legacy of Iowa girls' basketball has been captured in both popular press coverage and sport history scholarship. National media sources shined the spotlight on Iowa girls' basketball, particularly around state tournament time, as seen in publications such as the Wall Street Journal, New York Times, USA Today, Life, and Sports Illustrated. Published histories of the sport, including two issues of The Palimpsest (1950 and 1968), document and discuss the unique organization of the sport and the opportunities it provided. ${ }^{28}$

folded along with the league before competition even began. Wayne Grett, "Women's Cage Loop to Hit Ground Crawling," Des Moines Register, 8/8/1986; idem, "Status of Pride of Iowa in New NWBA Unclear," ibid., 10/3/1986; "The History of Women's Professional Basketball," Association for Professional Basketball Research, on-line database at www.members.aol.com/_ht_a/apbr basketball/women.html, accessed 1/10/2001.

28. William J. Petersen, R. H. Chisholm, and Jim Duncan, "Girls' Basketball in Iowa," Palimpsest 31 (1950), 45-76; ibid. 49 (1968), 113-60. Janice A. Beran, a professor in the College of Education at Iowa State University until her retirement in 1994, has done extensive research on Iowa's sport history, particularly on women and African Americans. Her publications on Iowa girls' basketball include From Six-on-Six to Full Court Press; "Iowa, Longtime 'Hot Bed' of Girls' Basketball," in Hult and Trekell, eds., A Century of Women's Basketball, 181-204; "Daughters of the Middle Border: Iowa Women in Sport and Physical Activity, 1850-1910," Iowa State Journal of Research 62 (1987), 161-81; "Playing to the Right Drummer"; "The Story: Six-Player Girls' Basketball in Iowa," in Reet Howell, ed., Her Story in Sport: A Historical Anthology of Women in Sports (New York, 1982), 552-63; and "The Iowa Girls' High School Basketball Tournament as an Institutionalized Ritual," in Alyce Cheska, ed., Play as Context (New York, 1981), 149-57. Additional references to the sport include Hult and Trekell's anthology, A Century of Women's Basketball, which contains several references to Iowa girls' basketball-beyond Beran's chapter-mostly pointing to the IGHSAU's positions on competitive basketball and rule changes. Cahn and Festle begin chapters with stories about Iowa girls' basketball in their work on twentieth-century women's sport. See also Helen Lenskyj, Out of Bounds: Women, Sport and Sexuality (Toronto, 1986); Shelley Lucas, "Courting Controversy: Gender and Power in Iowa Girls' Basketball," Journal of Sport History 30 
To demonstrate the unique opportunities for participation available to Iowa girls, consider this statistic: In the school year preceding the passage of Title IX (1970-71), 294,000 girls participated in high school sports across the country; 20 percent of those girls resided in Iowa! After Title IX became law in 1972, tremendous changes began to occur in sport programs across the country; by 1976, the number of participants had jumped to 1.6 million (with Iowa girls representing less than 6 percent of the total). ${ }^{29}$ Despite Iowa's reputation for providing high school girls with competitive sport opportunities, the IGHSAU and the 6-on-6 game faced scrutiny during the 1970s for the opportunities its basketball program denied Iowa 6-on-6 players: the ability to compete on a level playing field with female athletes from other states (the majority of which had adopted the 5-player rules) for college scholarships to play full-court basketball. ${ }^{30}$

The buildup to the Iowa Cornets' 1978-79 inaugural season occurred in the midst of the controversy over the high school girls' basketball rules. Just ten days prior to a momentous federal government announcement that it would not intercede in the rules controversy, ${ }^{31}$ the Cornets played their season home

(2003), 281-308; Max McElwain, The Only Dance in Iowa: A History of Six-Player Girls' Basketball (Lincoln, NE, 2004); and Pamela Grundy and Susan Shackelford, Shattering the Glass: The Remarkable History of Women's Basketball (New York, 2005).

\section{Beran, From Six-on-Six to Full Court Press, 99.}

30. The controversy over Iowa girls' basketball rules gained widespread public attention in Iowa when the game came under fire in the 1970s and early 1980s from a variety of legal challenges brought under and stemming from Title IX: a 1976 Tennessee court ruling declaring the 6-player game discriminatory, a 1978 investigation by the U.S. Department of Health, Education, and Welfare, a proposed antidiscrimination rule by the Iowa Civil Rights Commission in 1979 banning the game, and a federal lawsuit brought by three Iowa girls in 1983.

31. In the summer of 1978, Iowans learned that complaints about 6-on-6 had been filed with the Office of Civil Rights (OCR), a division of the Department of Health, Education, and Welfare (HEW). Those complaints came from a variety of sources and states, including N. Peggy Burke, a University of Iowa professor in the Department of Physical Education for Women, and Dorothy Stulberg, a Tennessee-based attorney (and former Iowan) who had recently filed a civil suit on behalf of a 6-on-6 player who felt the rules hampered her opportunity to earn a college scholarship. See Cape v. Tennessee Secondary School Athletic Association, 424 F. Supp. 732 (E.D. Tenn. 1976). OCR recommended that HEW Secretary Joseph Califano rule that 6-player basketball violated the rights of some players and declare the game unconstitutional. "HEW 
opener against the New York Stars at Veteran's Auditorium in Des Moines-home of the nationally recognized annual girls' high school basketball state championship. Alongside news coverage of the federal government's interest in 6-on-6 girls' basketball were stories describing the development of the Cornets' organization. The news media regularly featured information about the hiring of staff, recruitment of players, training camps, schedules, and half-time entertainment and often included references to Iowa girls' basketball. The publicity surrounding the Cornets reflected an awareness of the popularity of 6-on-6 and concerns over the legal challenges to the Iowa tradition.

The Cornets tried to foster and promote a relationship between the team and the legacy of Iowa's high school basketball program. Appealing to the national renown of Iowa's basketball tradition and recruiting former Iowa basketball standouts were two ways the Cornets acknowledged and gave tribute to the unique 6-on-6 program. Local newspaper coverage of the newly formed Cornets frequently linked team owner Nissen's enthusiasm for his venture to his understanding of "the long love affair Iowans have conducted with women's basketball" and his belief that Iowans were "as ripe an audience for women's pro basketball as can be found in the United States." A journalist predicted that "with the interest in Wayne Cooley's present Iowa girls' high school cage program ... the Iowa Cornets will have to be a success" - a sentiment the Cornets hoped would become a reality. ${ }^{32}$

Nissen reportedly believed that Iowa's legacy also lay behind film director Michael DeGaetano's vision for the musical

Shelves 6-player Ruling," 9/14/1978, Research files-girls' basketball, Newspaper clippings, box 2, Janice A. Beran Papers, IWA. See also Randy Peterson, "HEW to Decide Soon on 6-girl Basketball," Des Moines Tribune, ibid.; Des Moines Register, 8/1/1978, 9/28/1978. For a legal analysis of the civil actions concerning 6-on-6 basketball, see Sarah K. Fields, Female Gladiators: Gender, Law, and Contact Sport in America (Urbana, IL, 2005), 55-82.

32. "The WBL's First Franchise," unidentified clipping, General Information, 1978-1986, Iowa Cornets, box 1, Bolin Papers; Steve Kadel, "18 Women Willing to Bet on Iowa Pro Cage Team," Des Moines Register, undated, Newspaper clippings, 1978-1980, box 1, ICR; Bob Lana, "Iowa Cornets Set to Go in Women's Pro," Marion Sentinel, 6/22/1978, Newspaper clippings, 1978-1980, box 1, ICR. E. Wayne Cooley led the IGHSAU as executive secretary from 1954 until his retirement at age 80 in 2002. 


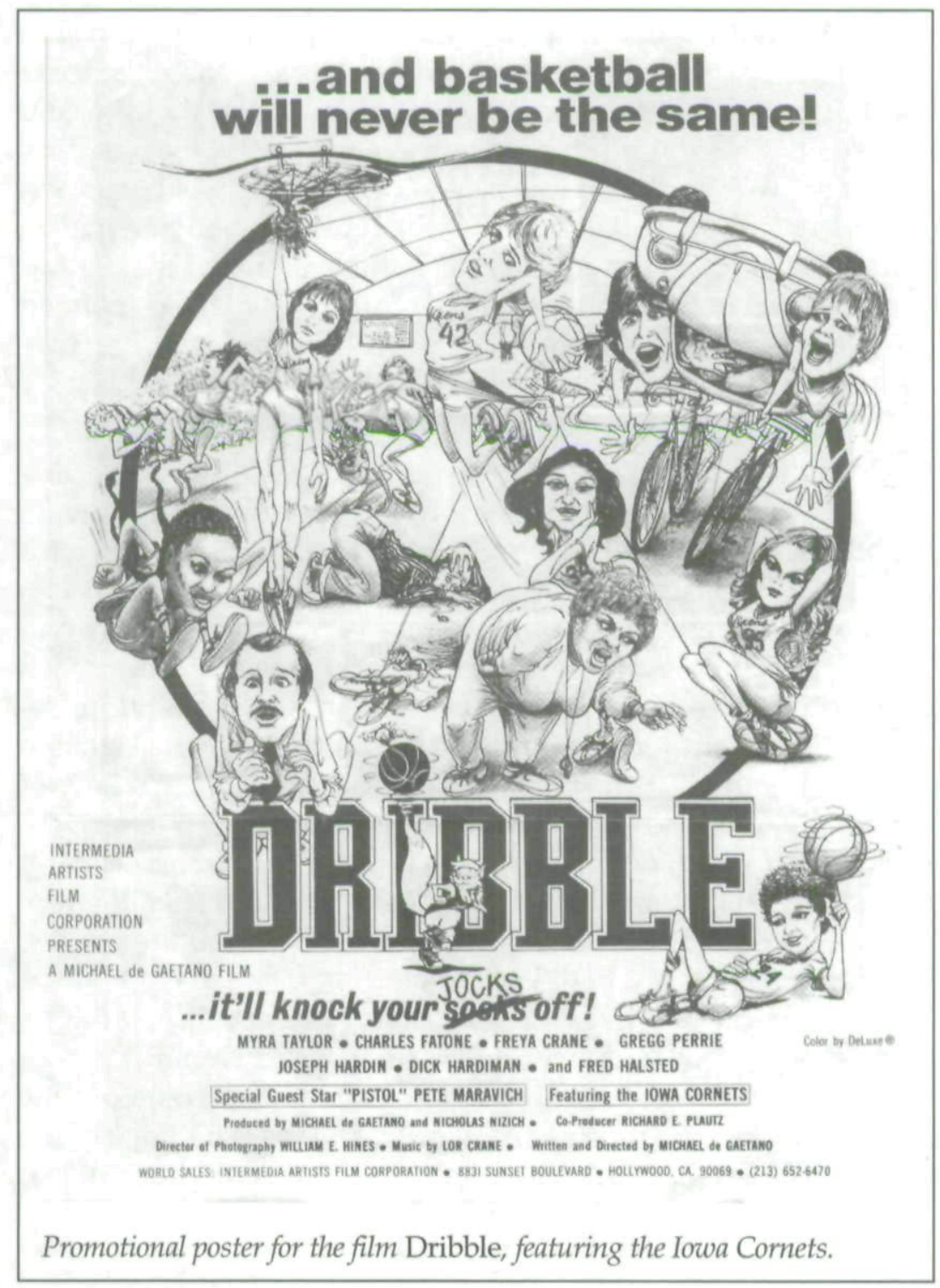

comedy Dribble, a low-budget Hollywood feature film about a financially struggling women's professional basketball team. The film, starring "Pistol" Pete Maravich, a well-known professional basketball player, was shot entirely in Iowa and featured a few Iowa Cornets. DeGaetano claimed that Iowa's status as 
"the capital of women's basketball" convinced him, long before the league developed, to set the story in Iowa. ${ }^{33}$ Nissen's financial backing of the film helped DeGaetano make the film and ensured that it would be shot in Iowa and include players from his team. In return, the Cornets secured press coverage and name recognition well in excess of the typical pre-season media. Promoters of women's professional basketball hoped that Dribble could help popularize the sport. Unfortunately, critics panned the film, and a Des Moines Register writer even expressed concern that it could set women's basketball back 20 years. ${ }^{34}$

FROM THE BEGINNING, owner George Nissen forged a strong Iowa connection for the Cornets, from the head coach to the players. George Nicodemus, the Cornets' first head coach (there would be several in the team's brief existence), had deep Iowa roots. An alumnus of the University of Northern Iowa and Iowa State University, he also had worked as a teacher-coach in Iowa for 19 years prior to coaching at the college level in Nebraska. Assistant Coach Bruce Mason and General Manager Rod Lein both had experience coaching Iowa women's basketball as well. Described as a longtime advocate of 6-on-6 girls' basketball, Coach Nicodemus appealed to the local market early on, hinting that he might sign only Iowa players. "I believe we can go largely with Iowans," he said, "if they have the interest and want to play pro ball. We're going to look real close at the Iowa prospects and the Iowa kids coming out of college now." 35 The Cornets scouted and courted former and current Iowa high school standouts as a way of showing respect for the 6-on-6 game and its athletes and earning the allegiance of its fans. Nine of the twenty women invited to the Cornets' tryout camp hailed from

33. Wayne Grett, "Fledgling Iowa Cornets to be Movie Stars, Too," Des Moines Tribune, 6/29/1978, Media coverage, 1978 and undated, Dribble, box 1, ICR.

34. Unidentified clipping, Des Moines Register, 9/11/1978, ibid. Dribble's juvenile plot involves a cash crop of marijuana, a Venus flytrap plant similar to the one in The Little Shop of Horrors, and women's teams named the Vixens, Hornets, and Omaha Beefeaters.

35. Mark Dukes, "TV, Playoffs, All-star Games in Cornet Future?" Cedar Rapids Gazette, 11/8/1978, Newspaper clippings, 1978-1980, box 1, ICR; "Pro Team Names Coach," Iowa Press Clipping Bureau, 3/30/1978, ibid. (quote). Most of the stories about Nicodemus's hiring carried this quote as part of their report. 
Iowa. ${ }^{36}$ Not surprisingly, the first player to sign a contract with the Cornets was a native Iowan. With great fanfare, the Cornets announced the signing of Molly Bolin, the high-scoring high school player and 1975 graduate of Moravia High School. Bolin became the first player to commit to the WBL and signed her contract in Governor Robert Ray's office (see cover). A fan favorite, Bolin made the all-star team both years with the Cornets and held the scoring title and collected co-MVP honors in her second season in the league. ${ }^{37}$

Publicity about the Iowa Cornets almost always included a reference or connection to the successful Iowa girls' basketball program. Not surprisingly, Cornets general manager Rod Lein, identified in a Cornets publicity brochure as an outspoken supporter of 6-on-6, attended all of the sessions of the 1978 high school state tournament to promote the Cornets and to scout future talent. The Cornets also promoted the IGHSAU. Advertisements for the high school state tournament appeared in Cornets game programs, and fans were invited to choose from the early season favorites and name their picks for which teams would make it to the state tournament. An order form for sportswriter Jim Enright's Only in Iowa: Where the High School Girl Athlete Is Queen (a book the IGHSAU published in 1976 about its sports successes) also appeared in a Cornets program. ${ }^{38}$ Iowa girls' basketball also received validation indirectly through media coverage of the Cornets games. In contrast to the lack of recognition from the sports media for most other WBL teams (which often meant the absence of minimal acknowledgment, such as a box score), ${ }^{39}$ local sportswriters in Iowa regularly reported on the Cornets' games and occasionally singled out Iowa

36. Gus Schrader, "Cornets Assemble," Cedar Rapids Gazette, ibid.

37. "Bolin First with Iowa," unidentified clipping, ibid.; Bob Dyer, "Molly," Des Moines Register, 11/13/1979, ibid.; Mike Swan, "Moravia's Bolin Garners Attention for WBL," Centerville Iowegian, 4/24/1981, Newspaper clippings and interviews, 1981-1997, box 1, Bolin Papers.

38. Jack Ogden, "Pro Team Will Play Some Games in C.R.," Newspaper clippings, 1978-1980, box 1, ICR; "The Iowa Cornets Hit the Road" [publicity brochure], Scrapbook, 1977-1978, Oral Roberts University folder, box 2, Rhonda Penquite Papers, IWA; Game Program, 12/17/1978, Iowa Cornets, 1978-1980, ibid.; Season Program, 1979-1980, box 1, ICR; Enright, Only in Iowa.

39. Festle, Playing Nice, 253-54. 
natives for their contributions to the game, thereby legitimizing the women's game and the value of the Iowa players.

Demonstrating knowledge of Iowa girls' basketball history, the Cornets extended a special invitation to try-out camp to Denise Long Sturdy, a 1969 graduate of Union-Whitten High School and owner of nearly every Iowa girls' scoring record at that time. Long once scored 111 points in a single game and was also the first woman to be drafted by the NBA. ${ }^{40}$ In a story titled "A Legend Attempts a Comeback," she was referred to as a "household word to those associated with girls' basketball in the state of Iowa." 41 Coach Nicodemus labeled her a legend in the whole country. The invitation to Long can be characterized as a promotional gimmick to appeal to Iowa girls' basketball fans. At age 27, a few years away from basketball, and with no particular interest in trying out for the team, Long really did not have a chance to compete against elite athletes playing full-court basketball. Although she had earned her legendary status playing by different rules than the professional game she was invited to try out for, the reporting highlighted her age (and lack of fitness) not the rules - as the key obstacle to her making the team.

Although she did not sign with the team at that time, the Cornets called on Long and her fame in 1979 when the organization faced financial difficulties. Owner-coach Rod Lein, an old friend of Long's, thought her name might draw a few extra fans and signed her for a few games. Long later described herself as "an old out-of-condition athlete sitting on the bench." Her stint with the Cornets amounted to 40 seconds of playing time and one point scored in a game. The highlight of her brief stint with

40. Kevin Simpson, "Denise Long, The Patron Saint of Girls' Basketball, Is Now 33," Los Angeles Times, 2/10/1985. Long was the number 13 pick of the Golden Gate Warriors in the 1968-69 National Basketball Association draft; see Enright, Only in Iowa, 48-62. At the time of the Cornets' invitation, her married name was Denise Long Sturdy. Some media accounts used her maiden name, Denise Long, presumably because of fan recognition-a practice also used to record IGHSAU Basketball Hall of Fame members. I follow that same convention for subsequent references to Long.

41. Howie Beardsley, "A Legend Attempts a Comeback," unidentified newspaper clipping, Newspaper clippings, 1978-1980, box 1, ICR. The invitation to Denise Long and her views on the new women's league and its possible effect on the Iowa girls' rules appeared in a number of press reports. See, for example, Schrader, "Cornets Assemble." 
the Cornets came in a game when fans cheered for her to be put in the game. Long explained:

We were playing at the Five Seasons Center in Cedar Rapids and all of a sudden one fan started chanting, "Put in Denise." Then, from the other side, someone yelled, "Put in Long." Before long the entire crowd was yelling and I couldn't believe it. Finally Rod turned to me and said, "I'm going to have to put you in or get lynched." I'll never forget that they gave me a standing ovation, even though Cedar Rapids didn't have high school ball when I played. ${ }^{42}$

The addition of Long to the Cornets roster not only added star power but, more significantly, brought another Iowa-born, 6-on-6 player to the team.

THE CORNETS not only recognized their historical and homegrown connections to the state of Iowa; they also took care to acknowledge the contemporary controversy that engaged many Iowans. Although the media often portrayed the controversy over the high school girls' basketball rules as a battle between feminists who supported the 5-player rules (most typically identified as women) and men who wanted to keep 6-on-6 (often coaches or those associated with the IGHSAU), the divisions in and between these main groups were actually quite complex. Numerous polls, studies, and debates illustrated differences of opinion about the rules across categories of age, gender, region of the state, and population (urban/rural). ${ }^{43}$ The traditions and uniqueness of Iowa's 6-on-6 game were central to arguments to leave the rules alone, and these were supplemented by concerns,

42. Chuck Burdick, "Denise Long, Girls' Basketball Legend, Named 100th Member in Hall of Fame," Des Moines Register, 4/18/1982, reprinted in "Iowa Sports Hall of Fame" at www.DesMoinesRegister.com/sports/extras/hall/ index.html, accessed 10/2/2001.

43. Measurements and indications of opinion on the rules controversy appearing before and during the Cornets' existence include Bob Hersom, "Iowa Girls Overwhelmingly Favor 6-Player Basketball," Cedar Rapids Gazette, 12/18/1976, Newspaper clippings, 1974-1978, Six-player girls' basketball, box 2, N. Peggy Burke Papers, IWA; Scott Hale, "Are Five Enough and Six Too Many?" The Iowa High School Athletic News, ca. 1977, ibid.; Randy Peterson, "Girls' Cagers in State Tourney Favor Iowa-style Game," Des Moines Tribune, 3/14/1977; Donna Suss, "Attitudes of Iowa Girls' High School Basketball Players and Coaches Concerning the Six-player Rules," Iowa Association for Health, Physical Education and Recreation Journal 10 (1978), 10-13. 
often voiced by IGHSAU coaches and administrators, that most girls did not have the physical skills necessary to play full-court basketball. Those advocating a switch to 5 -on- 5 constructed the issue primarily as a question of gender equity: boys did not face the same obstacles when competing for college scholarships and opportunities to play basketball beyond high school. ${ }^{44}$

Seeking to allay concerns rooted in the differences between the high school (6-player) and professional (5-player) rules, Coach Nicodemus highlighted the athleticism of former 6-on-6 players and emphasized that almost half of the Cornets team (6 of 14) had not played 5-on-5 in high school. (Actually, two of those six had not played high school basketball at all.) The Cornets included four native Iowans on the roster the first season and five the second season, and publicity indicated that several other members had close ties to Iowa. A few other Iowans did not make the team. ${ }^{45}$ One local sportswriter suggested that the selection of these players proved that playing 6-on-6 was not a deterrent to competing at the professional level. ${ }^{46}$ Nicodemus expressed pride in his Iowa players: "It's saying something if half the girls that were good enough to make your team never played five-girl high school ball. I believe that a good athlete is

44. For more on the arguments, characterizations, and media coverage of the rules controversy, see Lucas, "Courting Controversy."

45. Molly Bolin (Moravia), Connie Kunzmann (Everly), and Rhonda Penquite (Ankeny) played for the Iowa Cornets both seasons; Mary Schrad (Sioux City) participated in year one, and Nancy Wellen (Humboldt) and Pat Hodgson (Glenwood) were added for the second season. In college, these players had collected numerous scoring records and awards. Presumably, the Iowa players represented four of the six Cornets the first season who had not played 5-on-5 in high school. Denise Sharps also had no experience with 5-on-5 in high school because her Michigan high school did not sponsor a girls' basketball team. Sharps did play 5-on-5 women's basketball at Indiana State University. The identity of the sixth player is unknown, but given the lack of high school sports teams for girls in most states in the years preceding and immediately following Title IX (1972), she probably did not have a basketball program at her school, either. "The WBL's First Franchise"; "Team and Season Ticket Information," Publicity, 1978-79, box 1, ICR; Season Program, 1979-80, box 1, ICR; Dennis O'Grady, "Carroll's Schrad Now a Cornet," Carroll Daily Times Herald, 9/6/1978, Newspaper clippings, 1978-1980, box 1, ICR.

46. Jack Ogden, "2 Cornets Didn't Play Prep Basketball," unidentified newspaper clipping (probably the Cedar Rapids Gazette), Newspaper clippings, 1978-1980, box 1, ICR. 
able to adjust, and that we have some good athletes. To me, that shoots down the idea that six-girl ball is no good." 47 This statement echoed and supported one of the arguments put forth by 6-on- 6 advocates who claimed that the rules would not hold back top-level athletes wanting to play college ball.

At the same time, however, 6-on-6 supporters argued that a switch to 5 -on-5 would likely force out the defensive players (the guards) who did not have shooting ability. High school coaches pegged girls as forwards or guards based on the shooting ability they exhibited in their first days of organized basketball. A few years before becoming the Cornets general manager, then-Simpson College coach Rod Lein articulated a common refrain among coaches: "If a girl can't shoot, she is a guard, and if a girl shows a shooting ability, she's a forward, simple as that." 48 Based on this "natural born shooter" theory, because the 5-player game permitted all players to score points and the 6-player game did not (only half of the players on the court were allowed to shoot), guards would be at a disadvantage if the high school rules changed or if they pursued basketball after high school. Despite Lein's connections to the women's 5-player game at the college and professional level, he continued to express his support for 6-on-6. At a summer camp sponsored by the Cornets, Lein shared the opinion of a high school coach in attendance who advocated keeping the 6-player system so as to keep more girls on teams (an argument Cornet Rhonda Penquite disputes below). At the camp, high school players stated their preference for 5-on-5.49

Advocates of changing the rules to 5-on-5 responded to the argument that good athletes, even guards, could adjust to the

47. Dukes, "TV, Playoffs, All-star Games in Cornet Future?"

48. Rod Lein quoted in Randy Peterson, "Girls' Cage Ruling Angers Cooley; Sees Suit in Iowa," Des Moines Register, 12/2/1976, Newspaper clippings, 1974-1978, Six-player girls' basketball, box 2, Burke Papers. See also the statement by Coach Larry Niemeyer in Randy Peterson, "Girls' Basketball Controversy Renewed," Des Moines Register, 11/30/1976, ibid. Judging by my own experience growing up in Iowa, I would guess that coaches did not see me make any baskets that first day of Biddy Basketball in second grade, for I played the guard position from then until the end of high school.

49. Jerry J. Szumski, "Five Girls or Six? Iowans Jump to Center of Basketball Debate," Des Moines Register, 6/23/1979. 
full-court game with no problems by questioning how easily players who had not played in the forward position could transition to the 5-player game. Players argued that hard work and practice were necessary to acquire the art of shooting, and many guards admitted that they would be reluctant to try out for college basketball because they would lack that important skill. One player said she had "no experience in shooting, and it would take too much time to learn. By then, college would be over." 50 Discounting the "natural born shooter theory" articulated by Lein, these players did not doubt their ability, only the time it would take to learn new skills. Research conducted by University of Iowa professor N. Peggy Burke, a leader in the movement to change the girls' basketball rules, showed that the 6-player rules did discriminate against guards and that Iowa girls were falling behind at the college level. Colleges and universities awarded most athletic scholarships to forwards rather than guards, and scholarship opportunities continued to decrease for all Iowa players. ${ }^{51}$ The Iowa players on the Cornets roster fit that profile: all six players had, in fact, been highscoring forwards in their high school careers, and all played college ball.

Although the Cornets management glossed over the difficulties faced in the transition from 6-on-6 to 5-on-5, the players were not so ready to do so. The press often asked lowans trying out for the team to comment on the rules debate; their responses varied, but most were careful not to denigrate the system they grew up with. When asked directly, most of the Iowa

50. Quote from a Dysart-Geneseo player in Peterson, "Girls' Cagers in State Tourney Favor Iowa-style Game"; "Basketball Outcry," Des Moines Register, 1979, Research files-girls' basketball, Newspaper clippings, box 2, Beran Papers; Cindy Altmaier, "There's a Difference," letter to the editor, Des Moines Register, 7/22/1979; Suss, "Attitudes of Iowa Girls' High School Basketball Players and Coaches."

51. N. Peggy Burke, "Six-Player Basketball-From a Human Rights Viewpoint," Six-player girls' basketball, Reports, 1976-1978, box 2, Burke Papers; idem, "Iowa Girls' Six-player High School Basketball Discriminates, Burke Says," University of Iowa Women's Sports Relations, 11/8/1978, ibid. In 1977, 35 athletic scholarships were awarded to Iowa girls' basketball players, 29 to forwards, none to guards (6 were undocumented). In 1978, only 28 scholarships were granted, 23 to forwards. For more on Burke's role in the rules controversy, see Lucas, "Courting Controversy," Journal of Sport History. 
players admitted preferring 5-on-5 and predicted a rules change at the high school level to the full-court game. Identified as one of the few players to make such a successful transition to the 5player game (good enough to play at the professional level), Rhonda Penquite responded to a question from her hometown newspaper about where she stood on the high school rules issue: "'I prefer full court,' Rhonda says without hesitation. 'The argument is that under girls' rules the sixth player gets to play. But it takes eight to nine to play full court basketball.' " 52 Noting that while the 6-player game did not equip her for college or professional basketball, Molly Bolin was glad to have been a forward in high school because the scoring got her noticed. Bolin acknowledged that she had worked a lot on ball handling and defense, and now knew how to play the full-court game with only occasional lapses. She added that most of the good high school players at the summer camp sponsored by the Cornets preferred 5-on-5. Bolin also addressed the concerns about spectatorship: "Many people seem to think if Iowa High School girls basketball rules are changed to 'boys rules,' the sport will lose spectator interest. That's not true. First, five-on-five happens to be women's college, international and professional rules. Second, basketball can be fun and exciting regardless of the rules." 53 Denise Long also predicted that interest in the Cornets and the fans' exposure to 5-on-5 would eventually force a change in rules at the high school level. ${ }^{54}$ Debbie Franklin, a star high school player in Cedar Rapids who went on to play at William Penn College, received a "lot of flak" for her criticism of the 6girl game. When asked a few years later about her interest in playing for the Cornets, Franklin still favored the 5-player system, but had softened her views on Iowa's program, indicating

52. Rhonda Penquite quoted in Lois Anne Naylor, "Ankeny's Home Grown Cornet," Ankeny Press-Citizen, 1/25/1979, Career, Newspaper clippings, 19771980, box 1, Penquite Papers.

53. Quote from an untitled newspaper clipping, Des Moines Register, c. 1978, Scrapbook, 1978-1979, box 2, Bolin Papers; M. Howard Gelfand, "Perquisites Are Few for Women Cagers" (unidentified clipping), Newspaper clippings, 1979-1980 and undated, box 1, Bolin Papers; Szumski, "Five Girls or Six?"

54. "A Change in the Wind?" unidentified newspaper article, Newspaper clippings, 1978-1980, box 1, ICR. 
that she did not want the overall athletic program for girls to suffer due to a change in the rules. ${ }^{55}$

THE WBL'S INAUGURAL SEASON ended with Iowa losing to Houston in the final game of the championship series. For its second season (1979-80), the league expanded to 14 teams. The Cornets' marketing strategy expanded beyond its original boundaries as well. The new efforts to promote the team were more closely aligned with the WBL's strategies and drew the national narrative of the apologetic to the surface in Iowa. In addition to Molly Bolin's pin-up posters, the Cornets produced an advertising campaign (including television) that urged Iowans to "let the Cornets warm up your winter."

In commentary that reflected this mix of cornography and pornography, Des Moines Register columnist Chuck Offenburger questioned what he referred to as "sexy promotions" and "softcore cheesecake promotions," and later observed that it was very "Iowa-like" to have the state's first pin-up poster feature a female basketball player. At the start of the 1979 season, Offenburger's column featured an analysis of the Cornets promotions, Bolin's posters, and the physical appearance of players. When questioned about the team's promotional strategies, Cornets owner George Nissen offered a common apologetic response, which included references to the players' personal appearance and sexuality: "I don't think there's anything sexual about our promotions. But our players are all good looking kids who play basketball, and I don't think it's wrong to point out that they are not some kind of great big Amazons. Our advertising is a natural growth of that idea." Nissen's use of the term Amazon reflected and contributed to a long-standing practice of characterizing accomplished female athletes as "unattractive,

55. Once the WBL announced the Iowa franchise, players who excelled at the high school level in Iowa were approached and asked about their interest in trying out for the Cornets. Many of those players (some did not make or even try out for the team) were asked to comment on the high school rules debate. Jack Ogden, "Debbie Franklin Still Interested in Basketball," unidentified clipping (probably the Cedar Rapids Gazette), Newspaper clippings, 1978-1980, box 1, ICR. This article referenced a previous Gazette story in which Franklin was quoted on her views of the two types of basketball. 
failed heterosexuals" - a practice that diminished and debased female athletic achievements throughout the twentieth century. Countering those remarks, Offenburger tried to persuade his readers that the players" appearance (some are "pleasant looking" and some "downright ugly") were irrelevant to their jobs as professional athletes and urged Iowans to support the team: "They are rugged, well-trained athletes who are extremely good at what they do.... They are not Charlie's Angels." 56

Iowans did support the Cornets - at least to a greater extent than other WBL teams experienced - but it was not enough. Despite leading the league in attendance (drawing anywhere from 1,000 to 3,500 per game), consecutive second-place finishes, and the variety of marketing strategies described in the pages above, the Cornets suspended operations in the fall of 1980 during preparations for a third season. (The entire league would fold after the third season.) The owners cited financial difficulties due to a number of factors, including the failure of the film Dribble, which they had helped to finance, and an unusually harsh winter that kept fans at home. ${ }^{57}$ (Clearly, the second season's advertising campaign - "Let the Cornets warm up your winter" - failed to spark enough spectator interest or the warmth to draw fans out of their homes and into the cold.)

Sportswriters and 6-on-6 advocates alike had forecast the failure to fill the seats with paying fans. Sportswriter Gene Raffensberger reckoned that the financial backers of the Cornets had relied on Iowa's high school girls' basketball tradition to carry them: "Visions of sell-out crowds at Veterans Auditorium dance in their heads." But he wondered how well the full-court men's game-played by women - would go over with Iowa fans; women's college games, after all, were not drawing much of a

56. Chuck Offenburger, "It's a Big Day for Our Molly," Des Moines Register, 3/15/1986, Newspaper clippings and interviews, 1981-1997 and undated, box 1, Bolin Papers; idem, "Meet Supporter of the Cornets," Des Moines Register, 11/29/1979, Newspaper clippings, 1978-1980, box 1, ICR. For an excellent analysis of the use of the term Amazon to diminish and debase women's athletic accomplishments, see Cahn, Coming on Strong, 173.

57. Dan Johnson, "The Cornet Legacy," Des Moines Register, 7/28/1997, Newspaper clippings, 1997, box 1, ICR. The WBL managed to make it through the third season with nine teams, but teams and investors were simply losing too much money to continue. Festle, Playing Nice, 260-62. 
crowd. A few months into the season, the Des Moines Register asked, "Where are the Fans?" and reported on the general lack of interest (and attendance) in the women's game-both at the college and professional level. ${ }^{58}$

The supposition that Iowans were reluctant to watch women play by men's rules echoed common arguments put forth by those in favor of keeping 6-on-6 in the high schools. Although high school girls' basketball proved to be both popular among fans and profitable for the IGHSAU, one of the arguments in support of 6-on-6 warned that fans would not support 5-on-5 girls' basketball and speculated that the subsequent loss of revenue would hurt other girls' sports. ${ }^{59}$

Although farm-girl femininity was used to describe and promote some female basketball players in Iowa (primarily high school, but also some Cornets), the social acceptability of that femininity appeared rooted in distinctions between girls and women, and between the 6-player and 5-player games. Festle, for example, argues that "Iowa encouraged youngsters to excel at 'girls' basketball' but not women-women were expected to get married and raise a family." 60 An IGHSAU policy, which had been repealed in 1972 only after litigation, exemplified that argument. The policy, implemented in 1954, codified a distinction in gender roles by banning female students who were married or had children from playing high school basketball. E. Wayne Cooley, executive secretary of the IGHSAU, noted that "husbands and homes were the first obligations" for those students. (No similar regulations applied to male athletes who were fathers, husbands, or divorcés. $)^{61}$

58. Raffensberger, "Cornets Start Cage Dreams," Des Moines Register, 11/2/78, Newspaper clippings, 1978-1980, box 1, ICR; Wayne Grett, "Where are the Fans?" Des Moines Register, 2/25/ 1979, Scrapbook, 1978-1979, Iowa Cornets, box 1, Bolin Papers.

59. Beran, From Six-on-Six to Full Court Press, 102, notes that in the late 1970s 6-on- 6 basketball generated enough revenue to support 15 sports. See also Enright, Only in Iowa, 36, 223.

60. Festle, Playing Nice, 248.

61. E. Wayne Cooley quoted in Enright, Only in Iowa, 39-40. This policy, one of Cooley's first initiatives when he took over as executive secretary in 1954, stood for 17 years. In 1971 high school student Jane Christoffer Rubel filed suit against the IGHSAU on the basis that it prohibited her-a married student with a 
Concerns about gender surfaced in the rules controversy as well, when many supporters of 6-on-6 constructed boys' basketball (5-on-5) as too physical for girls - and too masculine. Award-winning Iowa high school girls' basketball coach Bud McLearn worried about the influence of 5-on-5 basketball on girls' femininity:

"I don't encourage my girls to play after high school," he says, "but that's really an individual thing. For some girls, it's okay, but not for all. If you play ball in college on a scholarship, you're leading the life of a jock. Four years of that and a girl will even start walking like a jock. The college game removes the femininity; I don't think the high school game does. ${ }^{62}$

His statement constructed both athletes and the full-court game as male, and included a veiled reference to sexuality. According to the logic implicit in McLearn's statement, female college basketball players became less like women (they lost their femininity) and more like men (walking like jocks) because they played a man's game (full-court basketball). His comments reveal the cultural tension between athleticism and womanhood identified by sport historians and sport studies scholars when theorizing about gender and sport. Girls' participation in a masculine domain (full-court basketball, for example) disrupted the sexual differences for which the two sets of rules had come to stand. And because sexual difference and gender were understood to predicate sexual preference, females who dared cross over the center line (meaning they played full-court basketball) simultaneously disturbed the sex/gender/sexuality equation. In other words, their sexuality was called into question.

For Molly Bolin, whose experiences encapsulated the transition from girlhood to womanhood and from the 6-player to the 5-player game, the shifting public perception of her identity

child - from playing on her high school basketball team. In 1972 the Federal District Court in Iowa ruled that the IGHSAU was in violation of both the Iowa and U.S. constitutions for forbidding married and divorced female students and students who were mothers from participating in high school sports. See the Jane Christoffer Rubel Papers, IWA; and IoWoman (January 1972), 3.

62. Chuck Offenburger, "Bud McLearn, the Compleat Coach," Des Moines Register, 6/9/1974, Newspaper clippings, 1974-1978, Six-player girls' basketball, box 2, Burke Papers. 
was troubling. Beginning her professional career with the Cornets as a wife and mother, she expressed surprise at the insinuations about her sexuality directed towards her later as a 25-yearold female athlete, divorced and living alone: "The image of the woman jock is not very favorable. ... In high school, everybody thinks it's great that the girls play basketball. And then I was wife and mother and also played basketball. That was fine. But once I was on my own, I was a jock. It was a real slap in the face to realize what some people will think of you." 63

After the Iowa Cornets folded, Bolin moved to California, where she played for two different San Francisco teams and was later involved with a number of other teams and leagues. Throughout her basketball career, she continued to promote herself, her femininity, and the sport with sexually charged photographs, posters, and commentary. Once she left Iowa, she did not permanently return. Bolin's disparaging comments about Iowa after she left (she was quoted in Sports Illustrated as stating that no one ever gets "famous by staying in Iowa" and mocking her endorsement options: tractors or manure ${ }^{64}$ ) and the reception of the ways she represented and marketed her image combined to create interesting and complex narratives about Iowa, Iowa girls' basketball, and the acceptance of women in sport in the late 1970s and early 1980s. Bolin's departure from Iowa and the narratives that later developed around her-such as the use of the pin-up posters against her in a child custody battle ${ }^{65}$-draw attention to the complicated web of local and national narratives that help to tell the story of women in sport.

SITUATED AT THE CONFLUENCE of social and historical forces, the story of the Iowa Cornets illustrates the intersection of local and national histories and discourses about gender, sport, and culture ${ }^{66}$ As political, legal, and social activism at the

63. Tracy Dodds, "Molly Bolin: A Pro in Search of a League," Times (possibly the Los Angeles Times), 2/26/1983, Newspaper clippings and interviews, 19811997, box 1, Bolin Papers.

64. Johnson, "The Lady is a Hot Shot," 33, 35.

65. Dodds, "Molly Bolin"; Porter, Mad Seasons, 221-29.

66. Jane M. Stangl, Commentary on "An Appreciation of 20th Century Local Histories" (presented at the annual meeting of the North American Society for 
national level reflected and shaped changing perceptions, attitudes, and opportunities for women-including those in the sport arena-Iowa continued to offer a high school girls' basketball game that did not respond to those changes. During that time, owners of the first franchise team in the newly formed WBL brought women's professional basketball to Iowa. The Iowa Cornets played by different rules and at a different level than the high school girls who consistently drew large crowds of basketball fans, family, and friends. Facing a spectator base that historically supported female athletics, the Cornets attempted to sell the team and the full-court game to Iowans by first highlighting unique aspects of Iowa culture and history: corn and high school girls' basketball. Together, those aspects encompassed farm-girl femininity and the rural heritage of girls' basketball. The Iowa Cornets took the legacy of Iowa girls' basketball seriously: the team's management drew on and promoted Iowa's talent pool (both coaches and players) and barnstormed around the state.

Several factors contributed to the failure of the Iowa Cornets (and the WBL a year later), but the effects of the rules controversy in Iowa offer a local and historically specific factor to consider. Although the Cornets banked on unique aspects of Iowa's culture and history, the turn to "apologetic" marketing strategies by the management and at least one player (Molly Bolin) indicates that the prevailing sexist and homophobic ideologies concerning women in sport in broader American culture were reflected in Iowa, notwithstanding the state's reputation for enthusiastically supporting highly competitive girls' basketball. Although investors and pundits speculated that Iowa, as the girls' basketball capital, would embrace the Cornets, Iowa proved not to be so unique when it came to women's professional basketball.

A few months prior to the announcement of the WBL's formation, womenSport magazine had published an article forecasting the difficulty of promoting women's professional basketball in a state such as Iowa. "When sports entrepreneurs started talk-

Sport History, London, Ontario, 5/26/2001). My thanks to Jane Stangl for her insightful commentary on local histories and the "Cornography" manuscript, in particular, which I presented in an earlier version at this conference. 
ing up a women's pro basketball league last fall, they pointed to the Iowa girls' basketball tournament as proof of the league's potential drawing power. What they didn't understand is that the Iowa tournament ... is as homegrown as the corn crop and can't be transplanted." 67 For the Iowa Cornets, a transplant would not be necessary; however, the game (and the league) did fail to take root-despite the liberal dose of cornography applied the first season.

67. Molly Tyson, "Iowa Fever," womenSport, December 1977, 27. 
Copyright of Annals of Iowa is the property of State of Iowa, by \& through the State Historical Society of Iowa and its content may not be copied or emailed to multiple sites or posted to a listserv without the copyright holder's express written permission. However, users may print, download, or email articles for individual use. 